\title{
Bioremediation of pendimethalin-contaminated soil
}

\author{
Belal, B. Elsayed ${ }^{1^{*}}$ and Mohamed F. El-Nady ${ }^{2,3}$ \\ ${ }^{1}$ Agricultural Botany Dep. (Agricultural Microbiology), Faculty of Agriculture, Kafrelsheikh Univ., 33516, Kafr El-Sheikh, \\ Egypt. \\ ${ }^{2}$ Agricultural Botany Dep. (Agricultural Botany), Faculty of Agriculture, Kafrelsheikh Univ., 33516, Kafr El-Sheikh, Egypt. \\ ${ }^{3}$ Department of Biology, Faculty of Applied Science, Taibah University, Almadinah Almunawwarah, P.O. 30002 Saudi \\ Arabia.
}

Accepted 26 April, 2013

\begin{abstract}
One strain of microorganisms was isolated from soil previously treated with pendimethalin using enrichment technique and identified using 16S rDNA as Pseudomonas putida (E15). The effect of pH and temperature on the growth ability of the tested strain was investigated. The results show that the optimum $\mathrm{pH}$ and temperature for the growth of pendimethalin dissipating strain were 7 and $30^{\circ} \mathrm{C}$, respectively. $P$. putida was used to dissipate pendimethalin from mineral liquid medium with half-live of 5.46 days. Pendimethalin half-live was $\mathbf{5 1 . 9}$ days in untreated mineral liquid medium. $P$. putida and compost were also evaluated for detoxification of pendimethalin in clay soil. $P$. putida and compost were effective in pendimethalin dissipation in soil with half-live of 4.67 and 5 days, respectively. Pendimethalin half-live was $\mathbf{6 2 . 4 3}$ days in untreated soil. Pendimethalin treatment affected analysis of the microbial population growing in $\boldsymbol{P}$. putida or compost treating soil leachates showed an overall increase in the population of microorganisms. There is no toxicity of pendimethalin detected in soil on cucumber plants after treatment with $\boldsymbol{P}$. putida or compost. Pendimethalin significantly decreased germination and increased cucumber seedlings mortality rate. $P$. putida and compost treatments increased the growth parameters. Moreover, no significant difference was observed in the most growth parameters between $P$. putida and compost treatments. Abnormal development of xylem tissue was observed in pendimethalin contaminated soil as a result of phytotoxicity. The results suggest that bioremediation by $P$. putida and compost was considered to be effective method for detoxification of pendimethalin in soil.
\end{abstract}

Key words: Pendimethalin, soil, biodegradation, phytotoxicity, seedling mortality.

\section{INTRODUCTION}

Pendimethalin (N-(1-ethylpropyl)-2,6-dinitro-3,4-xylidine) has the empirical formula $\mathrm{C}_{13} \mathrm{H}_{19} \mathrm{~N}_{3} \mathrm{O}_{4}$, a selective preemergent herbicide a dinitroaniline group, is used extensively for weed control in cotton, rice, soybean and tobacco (Smith et al., 1995). Pendimethalin acts by inhibiting the steps in plant cell division responsible for chromosome separation and cell wall formation. It is used before crop emergence or planting (Appleby and Valverde, 1988). The inhibition of root and shoot growth results in stunting of aerial plant Portions (Parka and Soper, 1977).
Studies in terrestrial ecosystems showed that $10-20 \%$ of the herbicide vaporizes within the first week or two week after application (Strandberg and Scott-Fordsmand, 2004). The observation of phytotoxicity to crops and weeds 200 days after application confirms that the dissipation time of pendimethalin is high enough to harm plants far beyond the period during which it is intended to be active (Stranderg and Scott-Fordsmand, 2004). The US Environmental Protection Agency (EPA) has classified pendimethalin as a persistent bioaccumulative toxic (PBT). 
Pendimethalin is also highly toxic to fish and aquatic invertebrates. However, it's use may adversely affect endangered species of terrestrial and semi aquatic plants and invertebrates including mollusks, fishes and birds. Care should be taken to minimize excessive pendimethalin applications to the soil in order to minimize possible injury to sensitive rotation crops. It is important to develop methodologies to prevent pesticide contamination from point sources. Microorganisms can use a variety of xenobiotic compounds including pesticides for their growth, mineralize and detoxify them (Belal et al., 2008). Bioremediation is an accepted technology for accelerating the rate of cleanup of contaminated water and soil. Soil microorganisms that are repeatedly exposed to pesticides may develop new capabilities to degrade such chemicals (Vidali, 2001). There are some reports on the degradation of pendimethalin by microorganisms comprising Azotobacter chroococcum, A. vinelandiiand Bacillus circulans (Saha et al., 1991; Singh and Kulashrestha, 1991; Kole et al., 1994; Megadi et al., 2010). The success of bioremediation depends not only on the high degradation ability but also on the stability of active microorganisms under varied conditions, such as changes in $\mathrm{pH}$ and temperature (Pattanasupong et al., 2004). Therefore, it is necessary to investigate the effects of various environmental factors on the growth ability of the tested microorganisms (Pattanasupong et al., 2004). On the other hand, it was found that various materials were used as soil amendments, nutrients, to increase and enhance the degradation potential of xenobiotics such as Yard manure compost (Guo et al., 1991; Cole et al., 1995; Gan et al., 1996; Zheng and Cooper, 1996; Vogel, 1996; Grigg et al., 1997; Leoni et al., 1997), biogas slurry and compost (Kadian et al., 2008; Belal et al., 2008). However, after remediation toxicity assessments are needed.

Firstly, is providing valuable and complementary information to compound analysis. Secondly, the major advantage of toxicity tests is the direct assessment of the potential hazard to the environmental system by both original pollutants and its metabolites (Tiainen et al., 2002). Therefore, this study attempted to isolate and identify efficient bacterial strain for bioremediation of pendimethalin in aquatic system and to evaluate this strain and compost in remediation of pendimethalin contaminated soil. In addition to confirm the complete detoxification of pendimethalin by measuring the toxicity of the treated soil in the presence of bacterial strain or compost against sensitive target such as cucumber plants.

\section{MATERIALS AND METHODS}

\section{Chemicals}

Pendimethalin (N-(1-ethylpropyl)-2,6-dinitro-3,4-xylidine) standard was obtained from Ehrenstorfer (Germany). All other chemicals were of analytical grade.

\section{Microbial degradation of the pendimethalin}

\section{Media}

Minimal medium as mineral salt liquid (MSL) and Luria Bertani (LB) a complete medium were used through this study as described by Sambrook et al. (1989).

\section{Isolation by enrichment culture}

Enrichment cultures of microorganisms capable of dissipating pendimethalin were established from soil previously treated with pendimethalin. Samples of soils were collected from Kafr El-Sheikh and Elbeheira, Governorates, Egypt. Ten grams soil were suspended in $90 \mathrm{ml}$ sterilized mineral salt medium in $500-\mathrm{ml}$ bottle containing $(100 \mu \mathrm{g} / \mathrm{ml})$ of pendimethalin as a sole source of carbon, then incubated at $30^{\circ} \mathrm{C}$ and $150 \mathrm{r} / \mathrm{min}$ for 28 days. Thereafter, $10 \mathrm{ml}$ of the cultures were transferred into fresh $90 \mathrm{ml}$ MSL medium containing the same concentration of pendimethalin. This procedure was repeated four times. Series dilutions were prepared after the final time from enrichment culture in a glass tube containing $9 \mathrm{ml}$ MSL medium up to $1: 10^{-6}$ and then $100 \mu \mathrm{l}$ of their were spread on plates of MSL medium + pendimethalin $(100 \mu \mathrm{g} / \mathrm{ml})$ using glass spreader. The plates were sealed in polyethylene bags, then incubated at $30^{\circ} \mathrm{C}$ for 7 days and monitored for appearance of colonies. Single colony growing on each plate was isolated by picking the colony using sterile inoculating needle and was further purified by the standard spatial streaking on complex agar media (Luria Bertani LB).

The isolated colonies were then tested for their ability to grow in MSL medium containing $(100 \mu \mathrm{g} / \mathrm{ml})$ of pendimethalin. The number of cells of each strain was determined by plating appropriate dilutions of liquid medium onto mineral salt agar medium containing pendimethalin. Bacterial populations were estimated by counting the number of colonies on plates.

\section{Identification}

The efficient selected pendimethalin degrading bacterial isolate was identified depending on the morphological and physiological characteristics as described by John (1984) and 16S rDNA as follow: DNA extraction was carried out following the CTAB method according to the method of Azadeh and Meon (2009). Oligonucleotide primer for 16S rDNA gene was 16S-1f (5'GCTAGTTGGTGGGGTAA-3', 17 mer) and 16S-2r (5'GCCATCTCAGTTCGGATTG-3'; $18 \mathrm{mer}$ ) were designed on the basis of the sequence of $E$. coli $16 S$ gene (corresponding to positions 247 to 263 and 1291 to 1309; E. coli numbering system). Amplification reaction for $P$. putida (E15) was performed according to the method of Wilems and Collins (1993).

The PCR products was purified using a commercial kit (QIA Quick PCR purification kit (Qiagen, Valencia, CA, USA), according to the manufacturer's instruction. After purification, the PCR products were sent for sequencing services at Sigma Co. Germany. The 16S gene sequences were aligned using BioEdit software versions 7.0.8 (http://www.mbio.nscu.edu/bioEdit) and searched for sequence similarity to other sequences which are available in the NCBI database at http://www.ncbi.nih.gov using Basic Local Alignment Search Tool (BLAST) algorithm. Multiple sequence alignments were performed on the selected closely related sequence accessions available using bioedit software (http://bioedit.edu/). Phylogenetic analysis was done based on the nucleotides sequences of 16S gene using mega4 or tree view software provided by the Biology Workbench Program (http://workbench.sdsc.edu/). Number of Data base JYZVMFRR015, K12FNS3P01S. 


\section{Effect of $\mathrm{pH}$ and temperature on the growth of the tested strain}

To determine the effect of temperature and $\mathrm{pH}$ on the growth of tested strain, a $30 \mathrm{ml}$ MSL medium supplemented with $100 \mu \mathrm{g} / \mathrm{ml}$ of pendimethalin was used as a sole source of carbon for bacterial strain. MSL medium was inoculated by $1 \mathrm{ml}$ from bacterial cell suspension at $10^{7} \mathrm{cfu} / \mathrm{ml}$. To determine the optimum $\mathrm{pH}$, experiments were carried out at $\mathrm{pH} 6,6.5,7,7.5$ and 8 . Cultures were incubated on a rotary shaker at $30^{\circ} \mathrm{C}$ and $150 \mathrm{r} / \mathrm{min}$ for 7 days. To determine the effect of temperature, MSL medium with $\mathrm{pH}$ of 7 was incubated at $20,25,30,35$ and $40^{\circ} \mathrm{C}$ under $150 \mathrm{r} / \mathrm{min}$. Cells number of the bacterial strain were determined by plating appropriate dilutions of liquid medium onto mineral salt agar medium containing pendimethalin.

\section{Dissipation of pendimethalin by $P$. putida (E15) in mineral liquid medium}

P. putida (E15) was cultured onto MSA medium + pendimethalin for 7 days and then the growing colonies were washed with $3 \mathrm{ml}$ sterilized MSL medium. The bacterial cell suspension $\left(10^{7} \mathrm{cfu} / \mathrm{ml}\right)$ was then used to inoculate $100 \mathrm{ml} \mathrm{MSL}$ medium containing (100 $\mu \mathrm{g} / \mathrm{ml}$ ) of pendimethalin. The cultures were incubated at $30^{\circ} \mathrm{C}$ and $150 \mathrm{r} / \mathrm{min}$ for $0,7,14,21$ and 28 days. The percentage of dissipation and the half-live of pendimethalin were determined as described afterward. Control flasks of equal volume of liquid mineral medium and pendimethalin without any microbial population were run in parallel at all intervals to assess a biotic loss.

\section{Bioremediation of pendimethalin contaminated soil and phytotoxicity test}

The phytotoxicity bioassay of pendimethalin was performed in the contaminated soil after 28 days treatment with $P$. putida (E15) and compost. Cucumber plants (Cucumis sativus L., cultivar Hisham) were used as the test organism. The phytotoxicity was determined as deformation in morphological and histological cucumber plants comparing to the treatments with $P$. putida (E15) and compost. All treatments were compared with the control treatment (untreated soil).

Clay soil with no previous history of pendimethalin concentration was collected from top $12-15 \mathrm{~cm}$ randomly following standard procedure and sieved through $2 \mathrm{~mm}$ size sieve (Gupta, 2000). The experiments were conducted in $1000 \mathrm{~g}$ capacity pots (polyethylene pots, $20 \mathrm{~cm}$ inner diameter and $30 \mathrm{~cm}$ in depth), each having 1000 $\mathrm{g}$ dried clay soil. Soil was contaminated with pendimethalin (100 $\mu \mathrm{g} / \mathrm{gm}$ soil) at $2 \%$ moisture level in their respective treatment pot before one week from cucumber sowing.

$P$. putida (E15) was cultured onto MSA + pendimethalin for 7 days and then the growing colonies were washed with $3 \mathrm{ml}$ sterilized MSL liquid medium. One hundred milliliter from cell suspension $\left(10^{7} \mathrm{cfu} / \mathrm{ml}\right.$ for bacterial strains) was then used to inoculate $1 \mathrm{~kg}$ clay containing $(100 \mu \mathrm{g} / \mathrm{gm})$ from pendimethalin before one week from cucumber sowing, mixed well and kept under incubation for 28 days at temperature $30 \pm 2^{\circ} \mathrm{C}$. Compost was used as soil amendments. The calculated quantity that is $100 \mathrm{~g}$ of compost was applied before sowing of trial in respective treatment pot, mixed well and kept under incubation for 28 days at $30 \pm 2^{\circ} \mathrm{C}$ (Belal et al., 2008) under greenhouse conditions. Five cucumber seeds of (Cucumis sativus L., cultivar Hisham) were sown in each pot after one week from soil contaminated with pendimethalin.

The residue half-live $\left(R L_{50}\right)$ for pendimethalin residues was calculated using the equation of Moye et al. (1987). Control pots of equal weight of soil and pesticide without any microbial population or compost were run in parallel at all intervals to assess a biotic losses as well as measuring of the botanical parameters on cucumber plants as follow:

\section{Growth characters and chlorophyll pigment contents}

Germination percentage was determined on the $15^{\text {th }}$ day from sowing. Percentages of seedling mortality were calculated as percentages of total number of germinated seeds. For seedlings characters, samples were taken at 15 days from sowing to estimate seedling hypocotyl length $(\mathrm{cm})$, fresh and dry weights of cucumber seedlings (dried in an oven at $70^{\circ} \mathrm{C}$ for $72 \mathrm{~h}$ ) g/plant. Chlorophyll a, $\mathrm{b}$ and total were determined in cotyledonary leaf and the first true leaf using spectrophotometer method as described by Moran and Porath (1980).

\section{Histological parameters}

The seedling hypocotyl specimens were taken from the middle region. The leaf specimens including the midrib were taken from the first true leaf. Specimens were taken on the $10^{\text {th }}$ day of sowing. Specimens were fixed in formalin alcohol acetic acid mixture (FAA, 1: 18: $1 ; \mathrm{v} / \mathrm{v}$ ), washed and dehydrated in alcohol series. The dehydrated specimens were infiltrated and embedded in paraffin wax $\left(52-54^{\circ} \mathrm{C} \mathrm{m}\right.$. p.). The embedded specimens were sectioned using a rotary microtome (Leica RM 2125) at a thickness of $8-10 \mu \mathrm{m}$. Sections were mounted on slides and deparaffinized. Staining was accomplished with safranine and azur II (Gutmann, 1995), cleared in xylol and mounted in canada balsam (Ruzin, 1999). Ten reading from 3 slides were examined with microscope (Lieca DM LS) with digital camera (Lieca DC 300), and then photographed. The histological feature of the hypocotyl was thickness of hypocotyl, vascular and cortex tissues as well as number of vessels/bundle. Moreover, the histological features of the first true leaf were thickness of lamina, midrib region, midrib vascular bundle, mesophyll (palisade and spongy tissues) and vascular tissues (xylem and phloem) in addition to the No. of vessels/midrib vascular bundle. The histological manifestation was calculated using Lieca IM 1000 image manager software. Lieca software was calibrated using $1 \mathrm{~cm}$ stage micrometer scaled at $100 \mu \mathrm{m}$ increment (Leitz Wetzler, Germany $604364)$ at 4 and $10 X$ magnifications.

\section{Analytical procedure}

Extraction and determination of pendimethalin residues was carried out by the described method of Jaźwa et al. (2009) at Central Agric. Pesticides Laboratory, Agricultural Research Center, Ministry of Agriculture and Land Reclamation, Egypt. Pendimethalin residue in soil was monitored weekly after application date. At each sampling time four soil samples were taken from randomly selected pots of cucumber plants. At the end of that test, pendimethalin residues were determined. Soil samples were air-dried, ground and stored at room temperature prior to analysis but no more than three days. Subsamples $(20 \mathrm{~g})$ were extracted by shaking for one hour with 100 $\mathrm{ml}$ of dichloromethane-acetone mixture $(9: 1 \mathrm{v}: \mathrm{v})$ on a rotary shaker. The extract obtained, was decanted by a layer of anhydrous sodium sulphate and the soil was rinsed two times with $10 \mathrm{ml}$ of dichloromethane (Ambrus et al., 1981; Luke et al., 1975, 1981; Sadło, 1998). The extract was cleaned using florisil (Valverde-Garcia et al., 1991). The analysis of the extract was performed using a Hewlett Packard 5890A gas chromatograph, equipped with a nitrogen phosphorus detector (GC-NPD). The column used in this study was an HP fused - silica capillary column coated with cross-linked methyl silicone (length $25 \mathrm{~m}$, ID 0.31 , film thickness $0.52 \mu \mathrm{m}$ ). Nitrogen was used as both the carrier and make-up gas at a flow rate of $30 \mathrm{ml} / \mathrm{min}$. Hydrogen was used at a flaw rate of $3.5 \mathrm{ml} / \mathrm{min}$. and air at $120 \mathrm{ml} / \mathrm{min}$. The oven temperature was programmed as follows: initial temperature $150^{\circ} \mathrm{C}\left(1 \mathrm{~min}\right.$.), rate of $10^{\circ} \mathrm{C} / \mathrm{min}$. and final tem- 
Table 1. Growth ability of the isolated bacterial strains in MSL supplemented with pendimethalin .

\begin{tabular}{ccc}
\hline \multirow{2}{*}{ Bacterial strain } & \multicolumn{2}{c}{ Growth ability (Log CFU/mI) } \\
\cline { 2 - 3 } & MSL (control) & MSL + pendimethalin \\
\hline E15 & 0 & 8.6 \\
E16 & 0 & 6.3 \\
E17 & 0 & 4.6 \\
E18 & 0 & 4.5 \\
E19 & 0 & 4 \\
E20 & 0 & 4 \\
B1 & 0 & 3.3 \\
B2 & 0 & 3 \\
Act1 & 0 & 2.3 \\
Act2 & 0 & 2 \\
\hline
\end{tabular}

perature $250^{\circ} \mathrm{C}$. Recovery studies were carried out regularly by spiking analytical samples with stock solution of pendimethalin standard.

\section{Statistical analysis}

Data were subjected to statistical analysis of variance according to the method of Gomez and Gomez (1984).

\section{RESULTS AND DISCUSSION}

\section{Isolation of the pendimethalin-dissipation isolates}

The pre-treated soil samples with pendimethalin were used to isolate the pendimethalin-dissipating microorganisms in the present study. By using enrichment techniques, a total of 10 morphologically different microorganisms capable of dissipating pendimethalin were isolated from the soil (Table 1). A preliminary classification based on the morphology of the isolates revealed that, the pendimethalin- dissipating microorganisms belongs to the group of bacteria. Six out of 10 bacterial isolates were Gram-negative, motile, rods and oxidase positive. Two out of 10 were Gram positive, motile, spore forming rod shaped bacterium as well as 2 out of 10 were Gram positive and filamentous shaped bacterium. Results in (Table 1) show that, one strain (E15) gave the highest growth on MSL medium supplemented with pendimethalin as the sole source of carbon comparing with the other strains. This indicates that this strain may show a high potential for pendimethalin degradation. The obtained results were compared with the growth of the strains in MSL medium only (no pendimethalin enriched). The bacterial isolates were also routinely streaked onto plates of LB for baterial isolate.

This bacterial strain (E15) was identified according to the morphological, physiological as well as using analysis of $16 \mathrm{~S}$ rDNA (Figure 1). This bacterial strain (E15) was Gram-negative, motile, rods and oxidase positive. According to the $16 \mathrm{~S}$ rDNA analysis, the phylogenetic tree of the isolated bacteria (E15) and related bacterial species based on the 16S rDNA sequence is provided in Figure 1. It can be clearly seen that the isolated bacteria was included in the genus Pseudomonas and closely related to the species P. putida. It showed the highest sequence similarities with P. putida F1 (98\%).

Our results are in agreement with previous finding reported by Kopytko et al. (2002), Karpouzas et al. (2005), Belal et al. (2008), Derbalah and Belal (2008) and Megadi et al. (2010). It was found that enrichment culture technique led to the isolation of two bacterial strains, which were able to degrade different pesticides rapidly in liquid cultures. The application of pendimethalin promotes the evolution of microorganisms that are capable of degrading this xenobiotic compound in the soil (Chaudhry and Ali, 1988). Chaudhry and Ali (1988) reported that, actinomycetes have considerable potential for the biotransformation and biodegradation of pesticides. Members of this group were Gram-positive bacteria and have been found to degrade pesticides with widely different chemical structures including organochlorines, striazines, triazinones, carbamates, organophosphates, organophosphonates, acetanilides, sulfonylureas and herbicide metolachlor (Krause et al., 1985; De Schrijver and De Mot, 1999).

\section{Effect of environmental factors (pH and temperature) on the growth of $P$. putida (E15)}

Normally, the $\mathrm{pH}$ and temperature influence the growth of microorganisms and hence, these factors will influence also the degradation process of the pesticides. Karpouzas and Walker (2000) reported the degradation of ethoprophos by P. putida strains epl and II affected by $\mathrm{pH}$ and temperature. Hong et al. (2007) found that various factors including $\mathrm{pH}$ and temperature affected degradation of fenitrothion-contaminated soil using Burkholderia sp. FDS-1. Belal et al. (2008) and Derbalah and Belal (2008) found also that the $\mathrm{pH}$ and temperature affected cadusafos, carbofuran and cymoxanil degrading microorganisms 


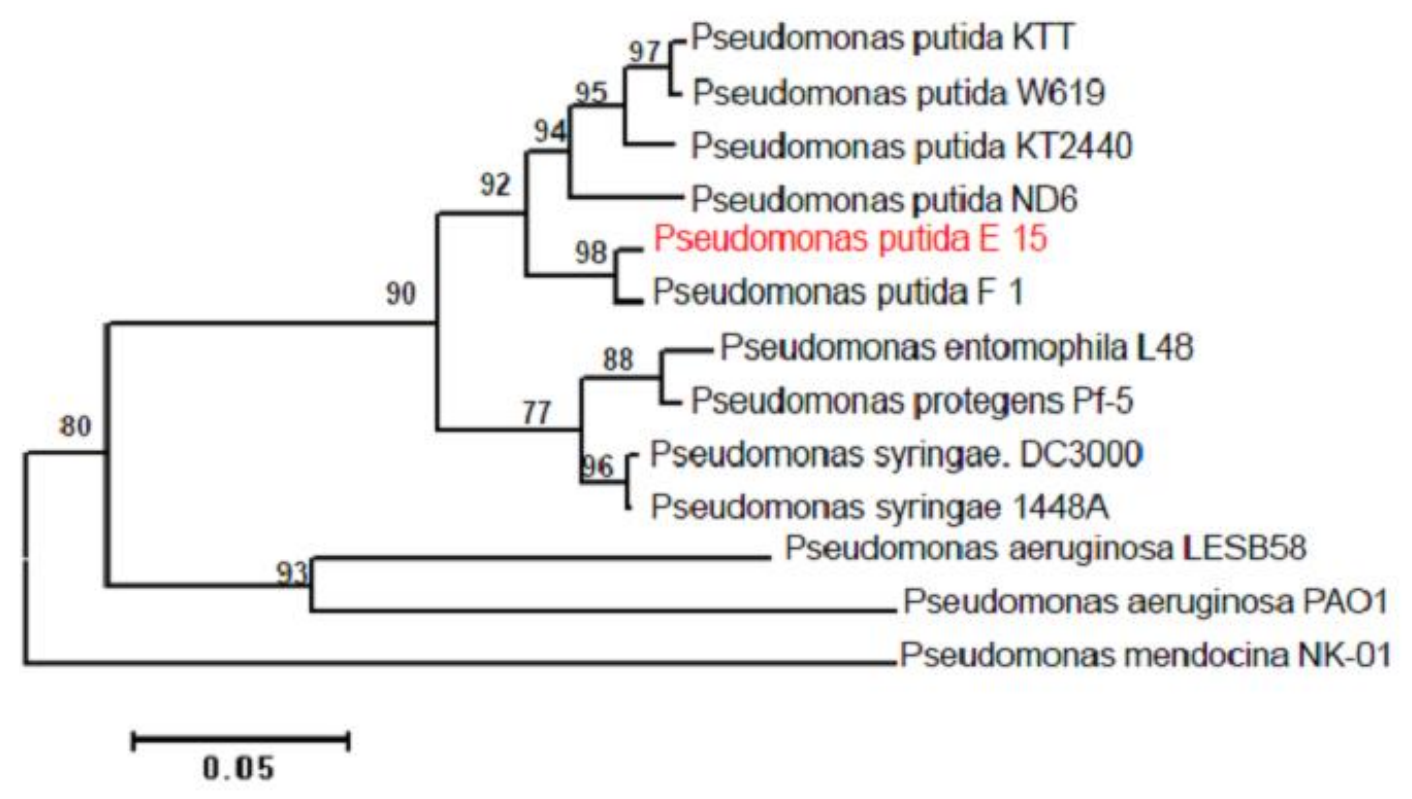

Figure 1. Dendogram illustrating the genomic relationship among seventy isolates belonging to genus Pseudomonas revealed by UPGMA cluster analysis.

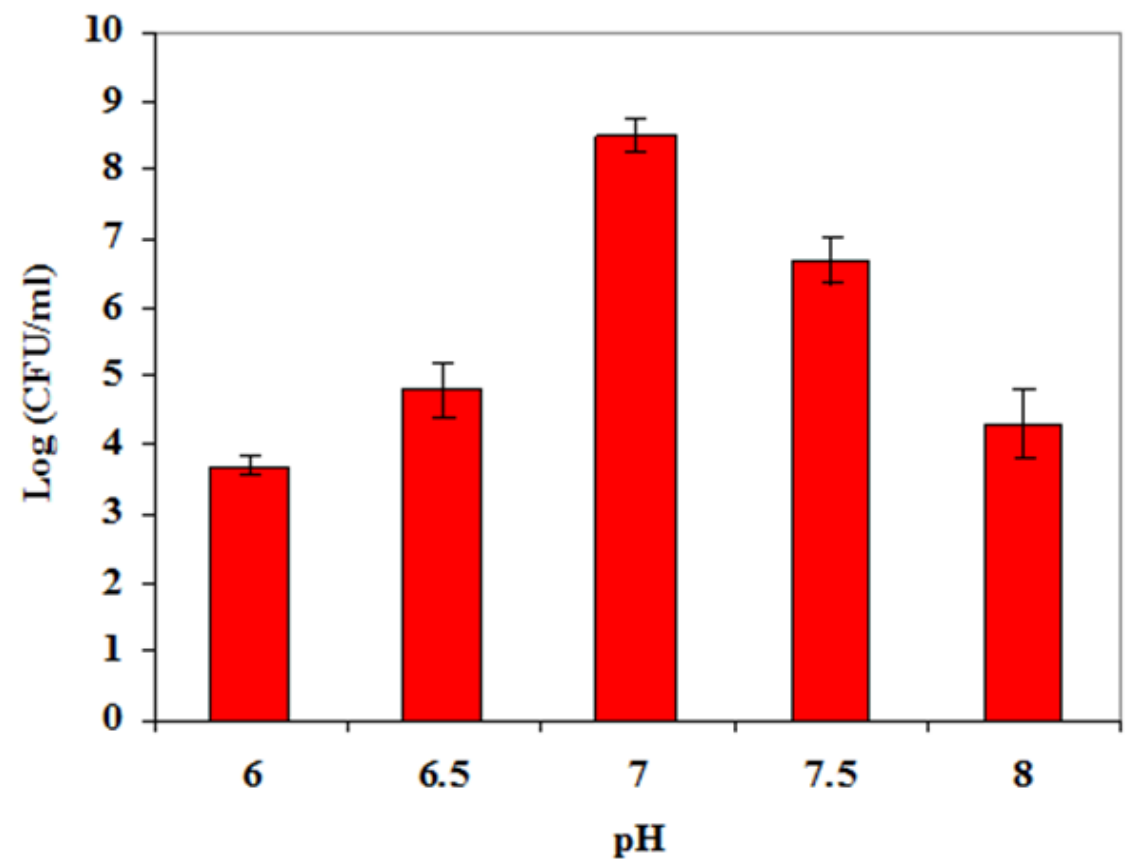

Figure 2. Effect of $\mathrm{pH}$ on growth ability of $P$. putida (E15).

comprising fungi and bacteria.

The influence of $\mathrm{pH}$ on biomass yield by the tested isolates is shown in Figure 2. Generally, the optimum pH was 7 for either bacterial or fungal isolates. Since, the maximum growth for $\mathrm{P}$. putida (E15) was recorded at $\mathrm{pH}$ 7 (Figure 2). It is known that the most of bacterial isolates prefer the neutral $\mathrm{pH}$. However, the tested bacterial strain in this study can grow at range of $\mathrm{pH}$ from 6 to 8 .
Ross and Marco (1978) reported previously that metalaxyl acid (N-(2,6-dimethylphenyl)-N-(methoxyacetyl)-alanine) resulting from the hydrolysis of the methyl ester group of pendimethalin was determined as the major metabolite in field soils at potato harvest and this may allow the degrading effect of metalaxyl.

The effect of different temperatures on the growth of $P$. putida (E15) is shown in Figure 3. The temperature of 


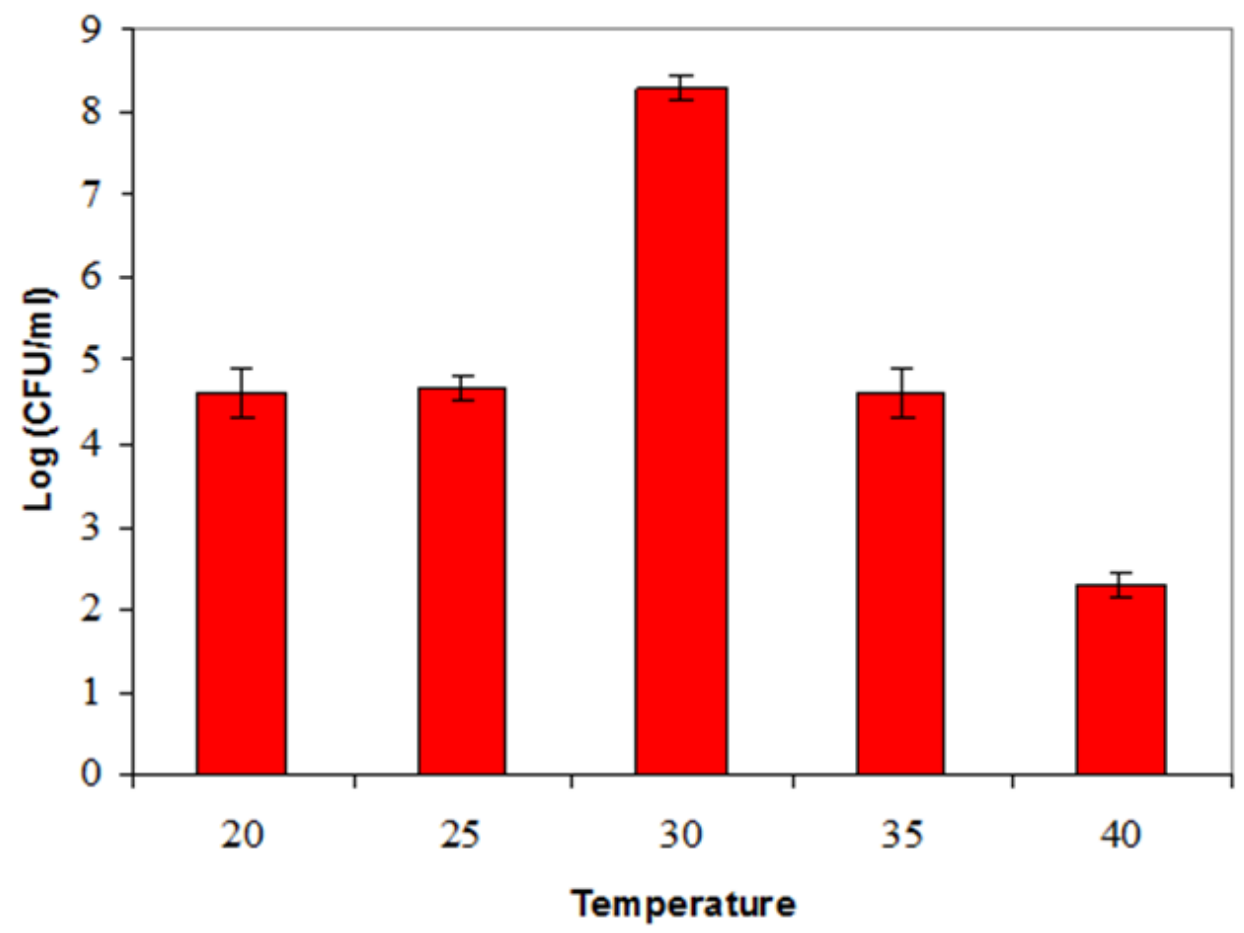

Figure 3. Effect of temperature on growth ability of $P$. putida (E15).

$30^{\circ} \mathrm{C}$ appears to be the optimum degree for growth of $P$. putida (E15). Moreover, the tested microbial isolates exhibited growth at $40^{\circ} \mathrm{C}$ of $P$. putida (E15) was used for further studies under the optimum growth conditions to evaluate their degradation potential for pendimethalin at different incubation times $(0,7,14,21,28$ days).

\section{Dissipation of pendimethalin by $P$. putida (E15) in mineral liquid medium}

The ability of $P$. putida (E15) to dissipate pendimethalin is illustrated in Figure 4. The results indicate that $P$. putida (E15) was the most efficient strain in pendimethalin dissipation with a half-live of 5.46 days. One hundred percent of pendimethalin initial concentration was dissipated within 4 weeks by $P$. putida (E15). Pendimethalin half-live was 62.43 days in untreated liquid medium as control treatment.

The growth response of pendimethalin $P$. putida (E15) increased gradually with the pendimethalin dissipation rate increasing as shown in Figure 4.

This is suggesting that different microbial types, which may be using different enzymes, have different degradation preferences. On the other hand, pendimethalin dissipation percentage reached to $17 \%$ at the end of incubation time in the control or non-inoculated samples. This implies that the quote of pendimethalin decay due to temperature effect and volatilization (Strandberg and ScottFordsmand, 2004). Many authors reported earlier that Pseudomonas has considerable potential for the bio- transformation and biodegradation of pesticides. Members of this group are Gram-negative bacteria and have been found to degrade pesticides with widely different chemical structures (Spain and Nishino, 1987; Kyria et al., 1997). The degradation of some pesticides may be attributed to the secretion of enzymes from either tested bacterial or fungal strains which are capable of degrading of pesticides (Bollag and Liu, 1990).

With regard to biological metabolization, in vitro degradation of pendimethalin has been demonstrated by numerous authors. For instance, Kole et al. (1994) observed that 45 and $55 \%$ metabolism of pendimethalin caused by Azotobacter chroococcum after 10 and 20 days of incubation, respectively. Azotobacter vinelandii was isolated from a pendimethalin-treated barley rhizosphere. A. vinelandii utilized pendimethalin as the sole source of carbon to fix N2 (Saha et al., 1991; Singh and Kulashrestha, 1991). Pendimethalin was degraded by oxidative $\mathrm{N}$ dealkylation to yield 3, 4-dimethyl-2,6-dinitroaniline and pentane. However, 6-aminopenimethalin and 3, 4dimethyl-2,6-dinitroaniline were not further metabolized because they neither supported growth of organism nor stimulated oxygen uptake. But the pentane, released by oxidative $\mathrm{N}$-dealkylation of pendimethalin, was utilized as the sole source of carbon and energy for the growth of the organism. The acetylation, aryl methyl oxidation and cyclization products of pendimethalin, as reported in Azotobacter chroococcum (Holding and Collee, 1971; Kole et al., 1994). Megadi et al. (2010) reported that pendimethalin degradation with Bacillus circulans was by 


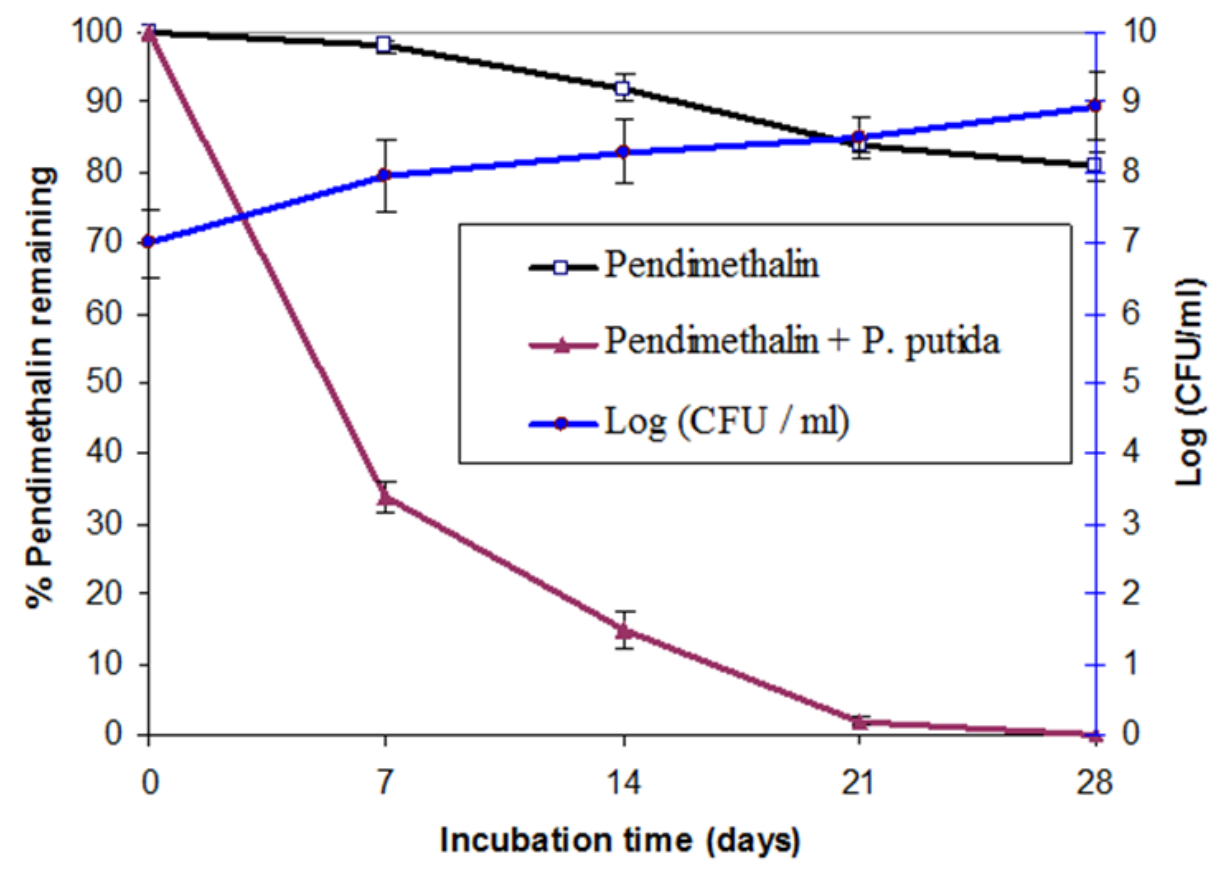

Figure 4. Dissipation of pendimethalin by $P$. putida (E15) in mineral liquid medium.

nitroreduction and oxidative $\mathrm{N}$-dealkylation via secretion of pendimethalin nitroreductase and pendimethalin N-dealkylase. The microbial degradation of dinitroaniline herbicides, pendimethalin and trifluralin has been repor-ted to occur most often by oxidative $\mathrm{N}$-dealkylation and nitroreduction. The nitro group reduction and oxidative $\mathrm{N}$ dealkylation destroys the herbicidal activity of pendimethalin, leading to its detoxification (Zayed et al., 1983; Singh and Kulashrestha, 1991; Kole et al., 1994; Megadi et al., 2010).

\section{Bioremediation of pendimethalin contaminated soil and phytotoxicity test}

Results in Figure 5A show the dissipation rate of pendimethalin by $P$. putida (E15) and compost in clay soil. Pendimethalin dissipation rate by $P$. putida (E15) was similar with compost. Pendimethalin half-lives were 4.67 and 5 days for P. putida (E15) and compost in clay soil, respectively. Pendimethalin half-live was 51.9 days in untreated clay soil. The loss of pendimethalin in untreated clay soil was $23 \%$ and this may be due to evaporation, dirft or leaching. The trend of dissipation rate of pendimethalin by bacterial strain and compost was similar in the tested clay soil. The obtained results showed that the bacterial strain and compost play an outstanding role in degradation of pendimethalin in clay soil. The results exhibited that increasing in loss of pendimethalin after initial phase (7 days), and thereafter dissipation of the pendimethalin increased gradually till the end of the incubation time 28 days and this may be due to accumulation of biodegradation products. Data in Table 2 show characterization of clay soil and compost.

The obtained results in Figure 5B showed that, pendimethalin treatments affected the analysis of the microbial population growing in $P$. putida (E15) or compost treated soil leachates showed an overall increase in the population of microorganisms. Pendimethalin treatment decreased the population of the microorganisms compared with the other treatments. The population of the microorganisms was reduced after one weeks and a slight stimulation was noted in the next weeks in pendimethalin treatment as compared with the unweeded control.

Biodegradation of pesticides in soil was reported with microorganisms and compost (Cole et al., 1995; Belal et al., 2008). Previous studies by Karpouzas and Walker (2000) have reported the isolation of two ethoprophosdegrading $P$. putida strains, which were also able to degrade cadusafos but in a less efficient way compared to the Flavobacterium and Sphingomonas strains. Flavobacterium strains have been reported to be responsible for the degradation of carbofuran (Chaudhry and Ali, 1988).

More potent strains that degraded pendimethalin rapidly were obtained from a soil samples which pendimethalin had been applied or exposed for a number of years or the time an enrichment technique. This indicates that repeated applications or exposure of soil or mature compost to xenobiotic compounds for a long period of time can result in the evolution of microorganisms capability of degrading these compounds rapidly and more extensively. 


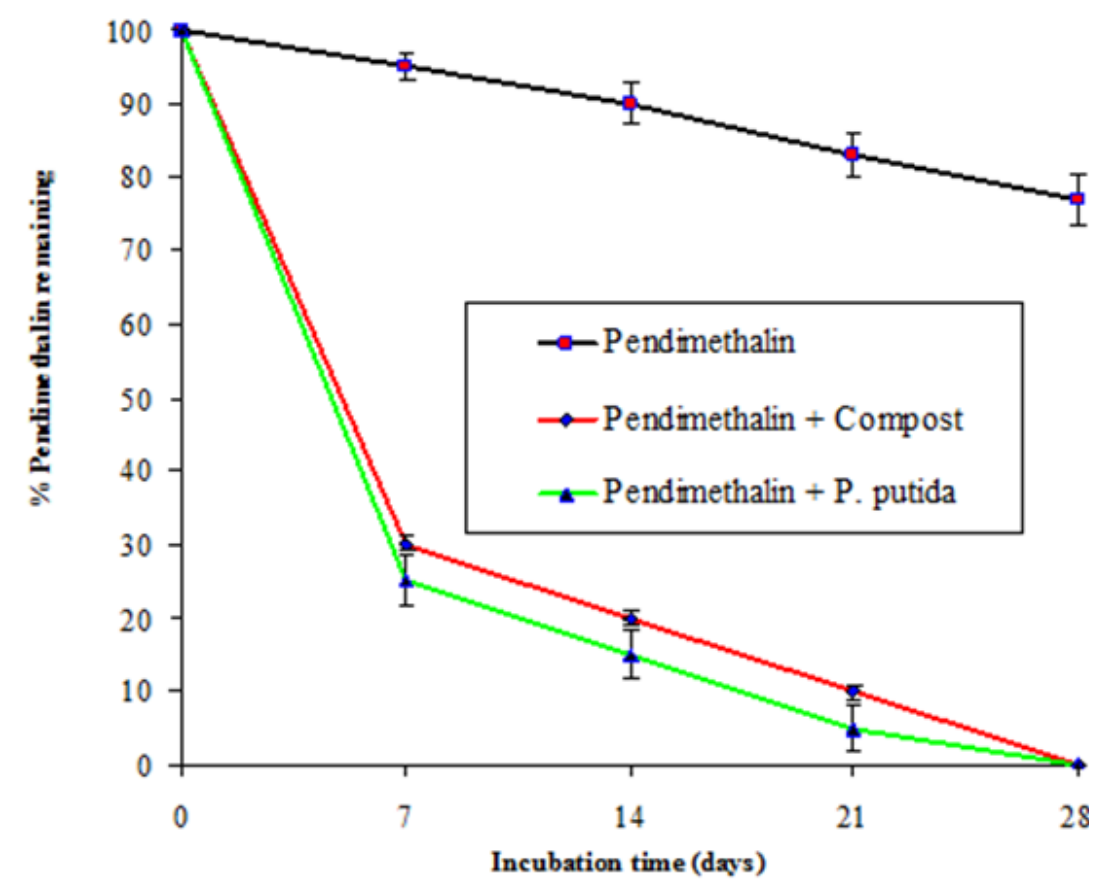

A

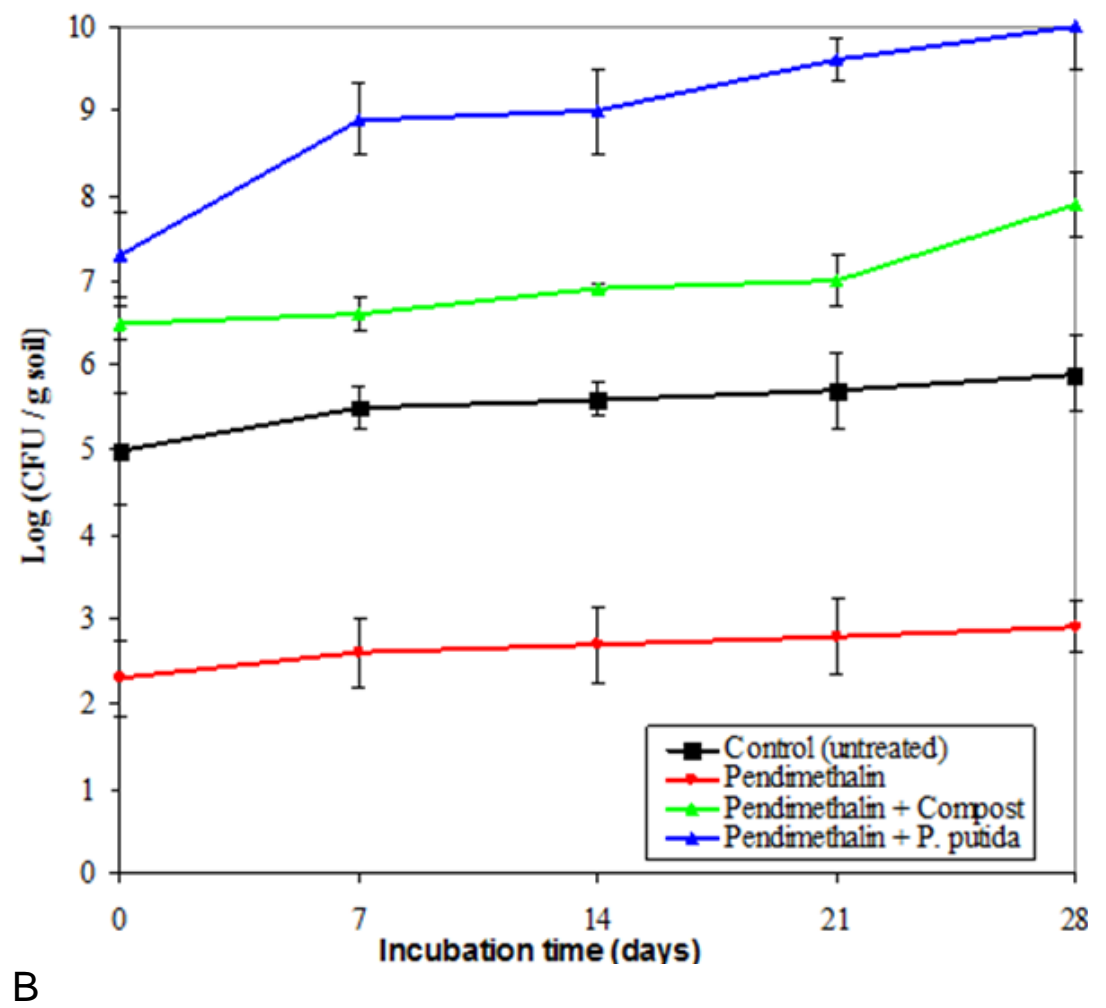

Figure 5. A, Disipation of pendimethalin contaminated soil by $P$. putida (E15) and compost; B, Population of microorganisms in pendimethalin contaminated soil.

Although addition of these bioprocessed materials has been an integral part of sustainable agriculture practices and offers a good nutrient source for microbes (Laine and
Jorgensen, 1996) and enhancers of microbial activity include moisture, inorganic nutrients, and oxygen. There are many well-established bioremediation technologies 
Table 2. Physicochemical characteristics of clay soil and compost.

\begin{tabular}{lcc}
\hline Parameter & Compost & Clay soil \\
\hline $\mathrm{pH}$ & 7.2 & 7.2 \\
Electrical conductivity & 1.8 & 2.2 \\
organic matter\% & 17.5 & 1.43 \\
Nitrogen (ppm) & 311.4 & 130.2 \\
Potassium (ppm) & 9.8 & 0.042 \\
Phosphates $(\mathrm{ppm})$ & 126.3 & 12.14 \\
Cadmium $(\mathrm{ppm})$ & 0.3 & 1.72 \\
Nickel $(\mathrm{ppm})$ & 0.83 & 3.04 \\
Lead $(\mathrm{ppm})$ & 1.3 & 9.5 \\
Manganese $(\mathrm{ppm})$ & 5.2 & 7.98 \\
Copper (ppm) & 3.5 & 4.44 \\
Iron (ppm) & 10.1 & 13.26 \\
Seed germination test \% & 93 & 92 \\
Total count of microorganisms & $6 \times 10^{6} \mathrm{cfu} / \mathrm{g}$ & $1 \times 10^{5} \mathrm{cfu} / \mathrm{g}$ \\
Phytopathogenic agents (fungi, bacteria and nematodes) & Negative & Negative \\
Total coli form counts & Negative & Negative \\
Total Salmonella counts & Negative & Negative \\
\hline
\end{tabular}

applied commercially at contaminated sites. One of such technology is the use of compost material and biogas slurry. Compost is rich sources of microorganisms, which can degrade contaminants to innocuous compounds such as carbon dioxide and water.

Earlier studies have also reported that bioprocessed materials such as compost and biogas slurry were used to degrade atrazine herbicide in contaminated soil using various bioprocessed materials (Cole et al., 1995; Kadian et al., 2008). Due to their high organic matter content, all bioprocessed materials accelerated cadusafos and carbofuran breakdown. Earlier studies have also reported high microbial biomass in soil that received the organic carbon amendment (Drenovsky and Richards, 2005), who found that addition of compost provided a rich source of microorganisms. Production of compost with a high nutritional content, that could be further used as inocula for the treatment of hazardous waste. Kulshrestha and Singh (1992) observed that $11-14 \%$ of pendimethalin degradation could be attributed to microbial transformation in sandy soil after 91 day. Oliver (1979) reported that, after application to soil, pendimethalin may dissipate through evaporation, drift, leaching, and runoff. A laboratory experiment simulating winter conditions showed that as much as $10 \%$ of the applied pendimethalin (0.6 mg/kg applied) evaporated if it was applied on the soil surface. Nayak et al. (1994) investigated the effect of pendimethalin on populations of bacteria, fungi, and actinomycetes in sesame soil (sandy loam, $\mathrm{pH} 5.8$, available $\mathrm{N}, \mathrm{P}$, and $\mathrm{K} 21,23.7$ and $53.75 \mathrm{~kg} / \mathrm{ha}$, respectively) at Bhubaneshwar, India. The dilution plate method was used to enumerate populations of bacteria, fungi, and actinomycetes from soil samples. It was found that pendimethalin $(0.5 \mathrm{~kg} / \mathrm{ha})$ significantly reduced bacteria
(61\%) after 25 days but not after 50 and 75 days, at which time a slight stimulation was noted as compared with the unweeded control. Fungi were significantly reduced by $19 \%$ after 25 days and stimulated after 50 and 75 days as compared with unweeded control. Actinomycetes were substantially reduced by $21 \%$ after 25 days and stimulated after 50 and 75 days. Sidhu et al. (1985) and Barua et al. (1991) studied the effect of pendimethalin on populations of fungi, bacteria, and actinomycetes. A significant decrease was observed on the first few days after the application, but after a period of 6 weeks, recovery to the level of the control was reached or almost reached. Bacteria were almost unaffected after 42 days, while actinomycetes were the most one.

\section{Phytotoxicity assessment}

The effect of the remaining toxicity of pendimethalin in clay soil on germination, growth and anatomical characters of cucumber plants was estimated after treatment with compost and $P$. putida (E15).

The results in Table 3 show the influence of the remaining toxicity of pendimethalin in clay soil on germination and seedling mortality percentage of cucumber seedling after treatment with compost and $P$.

putida (E15). Pendimethalin caused the highest value in reduction germination and increasing seedling mortality percentage of cucumber seedling compared with the control treatment. These parameters were improved with compost and $P$. putida (E15) treatment compared with pendimethalin treatment. Compost treatment was more effective in the reduction of seedling mortality compared with $P$. putida (E15) treatment. The efficacy of compost and $P$. putida (E15) was similar in increasing germination 
Table 3. Effect of the remaining toxicity of pendimethalin in clay soil on cucumber seed germination and seedling mortality percentage after treatment with compost and $P$. putida (E15).

\begin{tabular}{lcc}
\hline Treatment & \% Germination & \% Seedling mortality \\
\hline Pendimethalin & 80 & 25 \\
Pendimethalin + Compost & 90 & 11 \\
Pendimethalin + P. putida (E15) & 87 & 18 \\
Control & 92 & 0 \\
LSD $(0.05)$ & 3.52 & 4.6 \\
\hline
\end{tabular}

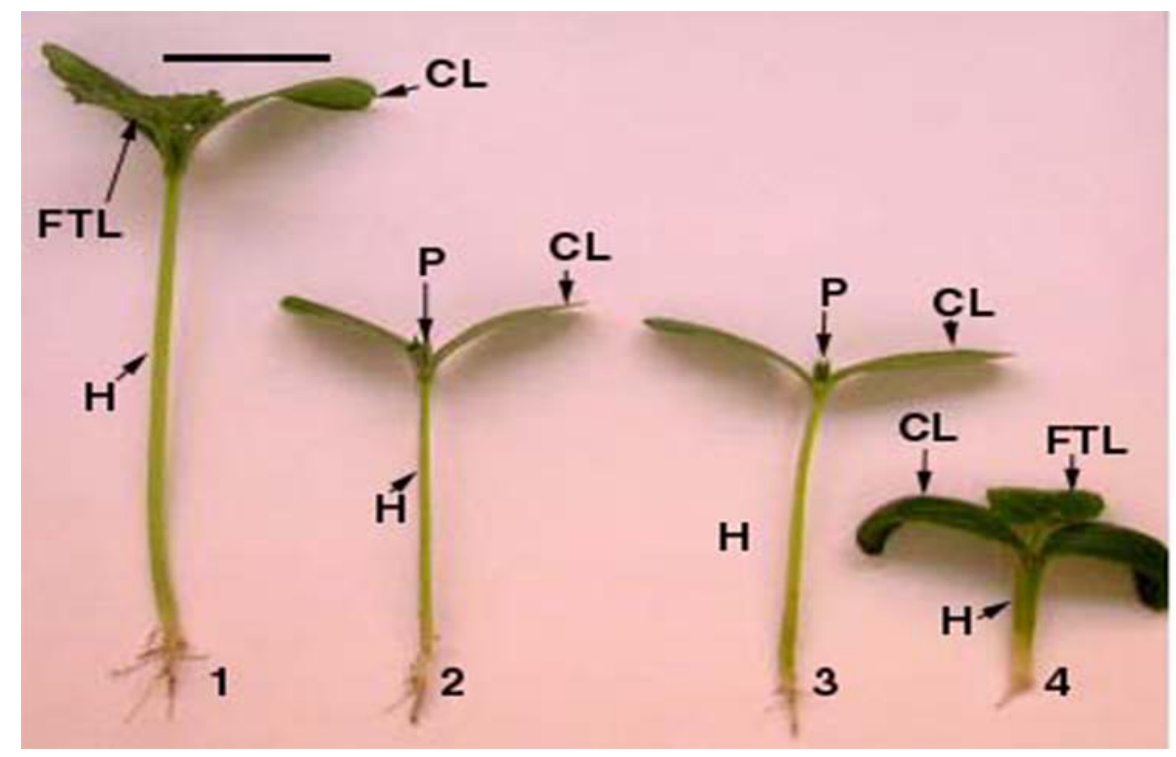

Figure 6. Cucumber seedling 15 days after sowing, 1- Control (untreated), 2Pendimethalin + Compost, 3- Pendimethalin + P. putida (E15), 4- Pendimethalin; Hypocotyl $(\mathrm{H})$, Cotyledonary leaf $(\mathrm{CL})$, Plumule $(\mathrm{P})$, First true leaf $(\mathrm{FTL})$, Bar $=3 \mathrm{~cm}$.

percentage of cucumber seedlings compared with pendimethalin treatment. All treatments were compared with unweedded treatment (control) after 15 days from sowing.

Data presented in Table 4 and Figure 6 illustrate the effect of the remaining toxicity of pendimethalin in clay soil on hypocotyl length and fresh and dry weight of cucumber seedlings after treatment with compost and $P$. putida (E15). The plant parameters (hypocotyl length, fresh and dry weight) of cucumber seedlings were reduced in the case of treatment with pndimethalin compared with other treatments. These parameters increased with compost and followed by $P$. putida (E15). The control (without pendimethalin) treatment recorded the highest value for the measured plant parameters compared with the other treatments. Pendimethalin treatment reduced the measured botanical parameters more than the other treatments and this is due to pendimethalin residues in soil which were 95,30 and $25 \%$ with pendimethalin, compost and $P$. putida (E15) treatments, respectively. These plant parameters were improved gradually when pendimethalin residues disappeared.
Application of pendimethalin significantly increased chlorophyll pigment (chlorophyll a, chlorophyll b and total contents of chlorophyll) in cotyledonary and the first true leaf of cucumber seedling compared with the other treatments. Chlorophyll pigment contents in cotyledonary leaf were higher than in the first true leaf (Table 5). It is interesting to note that, the increase in chlorophyll pigment contents is accompanied with the increase in mesophyll tissue thickness (Table 5 and Figure 7).

The hypocotyls internal structure of cucumber is similar to stems of dicotyledon plants. The hypocotyl structure of cucumber plants as seen in transverse sections consists of the epidermis, ground tissue and vascular system (Figure 7). The regions between the bundles are parenchymatous. The vascular bicollateral bundles arranged in complete cylinder (Siphonostele: eustele). Two types of bicollateral vascular bundles are present, tha is, large and small bundles. Data presented in Table 6 and Figure 7 revealed that, effect of the remaining toxicity of pendimethalin in clay soil on some anatomical parameters of cucumber seedling hypocotyl after treatment with compost and $P$. putida (E15). 
Table 4. Effect of the remaining toxicity of pendimethalin in clay soil on hypocotyl length, fresh and dry weight of cucumber seedlings after treatment with compost and $P$. putida (E15).

\begin{tabular}{lccc}
\hline Treatment & Seedling hypocotyl length (cm) & Fresh weight (g/seedling) & Dry weight (g/seedling \\
\hline Pendimethalin & 3.1 & 0.521 & 0.057 \\
Pendimethalin + Compost & 6.2 & 0.986 & 0.113 \\
Pendimethalin + P. putida (E15) & 6 & 0.882 & 0.104 \\
Control & 9.4 & 1.886 & 0.284 \\
LSD $(0.05)=$ & 1.23 & 0.102 & 0.005 \\
\hline
\end{tabular}
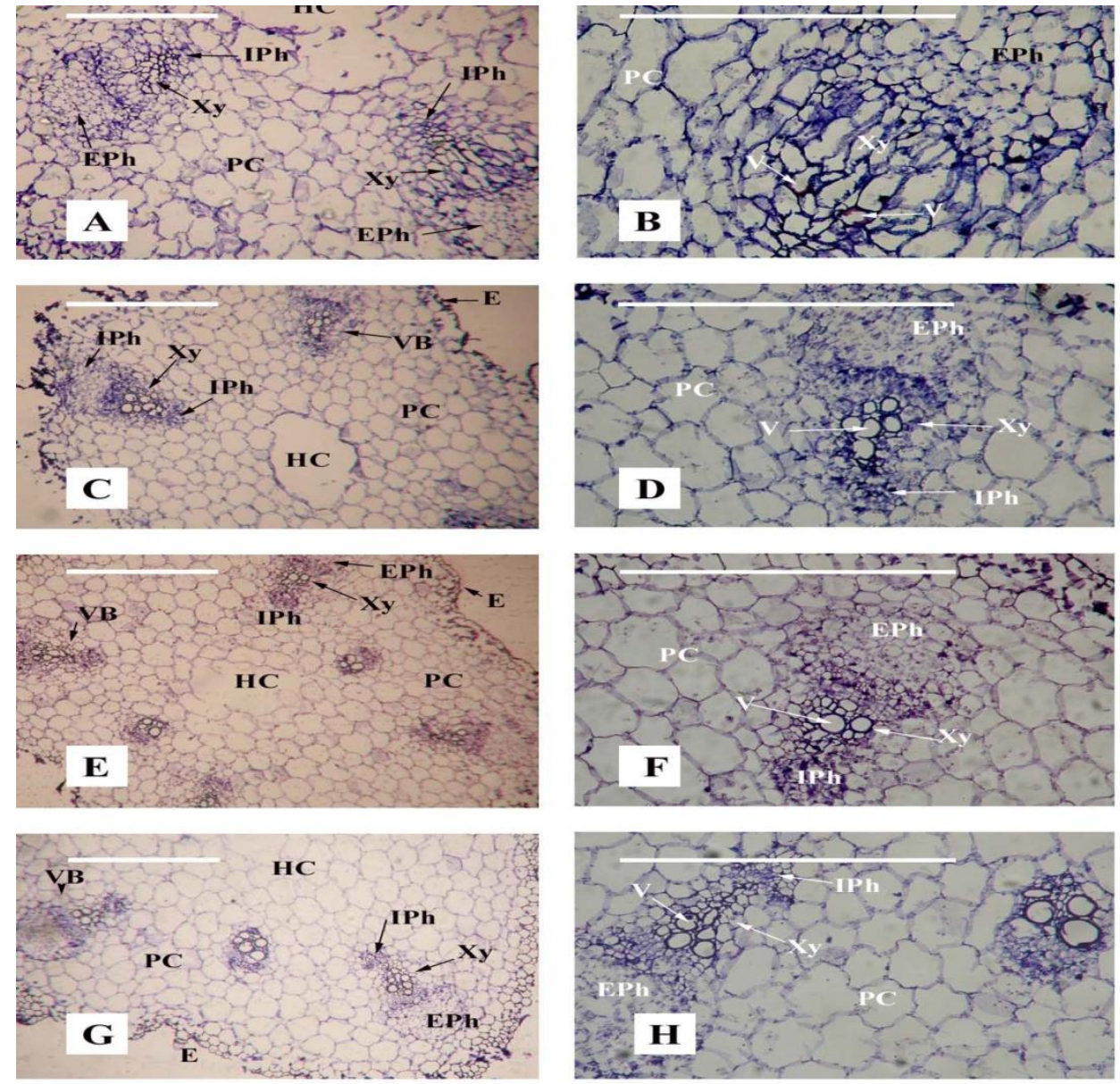

Figure 7. Cross sections through cucumber hypocotyle, A-B: Pendimethalin, C-D: Pendimethalin + P. putida (E15), E-F: Pendimethalin + Compost, G-H: Control (untreated), Hypocotyls cavity (HC), Xylem (Xy), External phloem (Eph), Internal phloem (IPh), C = Cortex (Co), Vessel $(\mathrm{V})$, Bar $=500 \mu \mathrm{m}$.

Application of pendimethalin increased seedling hypocotyl cross section, cortex and conductive vascular tissues (xylem and phloem) thickness compared with other treatments.

On the other hand, the lowest number of vessels per bundle was reduced by pendimethalin treated soil in comparison with the other treatments. Application of compost and $P$. putida (E15) decreased these anatomical parameters compared to the control. Abnormal development of xylem tissue was noticed by pendimethalin treated soil treatment as a result of phytotoxicity.

The leaf lamina internal structure of cucumber plants is similar to other dicotyledons plants. It consists of upper and lower epidermis and mesophyll tissue, which differentiate into palisade and spongy parenchyma. Epidermis, one layer of completely arranged parenchymatous cells, which are flattened parallel to the leaf surface. The palisade parenchyma cells are elongated and completely 
Table 5. Effect of the remaining toxicity of pendimethalin in clay soil on chlorophyll pigment (a, b and total chlorophyll) of cotyledonary and the first true leaves of cucumber seedlings after treatment with compost and P. putida (E15).

\begin{tabular}{lcccccc}
\hline Treatment & \multicolumn{2}{c}{ Chlorophyll content in cotyledonary leaf } & \multicolumn{3}{c}{ Chlorophyll content in the first true leaf } \\
\hline & chlorophyll a & chlorophyll b & $\begin{array}{c}\text { Total } \\
\text { chlorophyll }\end{array}$ & $\begin{array}{c}\text { Chlorophyll } \\
\text { a }\end{array}$ & chlorophyll b & Total chlorophyll \\
\hline Pendimethalin & 8.21 & 3.80 & 11.09 & 7.61 & 3.39 & 11.02 \\
Pendimethalin + Compost & 6.76 & 2.97 & 9.73 & 4.43 & 1.90 & 6.33 \\
Pendimethalin + P. putida (E15) & 5.5 & 2.48 & 8.02 & 4.35 & 2.18 & 6.52 \\
Control & 6.76 & 3.32 & 10.08 & 5.15 & 2.30 & 7.85 \\
LSD $(0.05)=$ & 1.18 & 0.43 & 1.001 & 0.70 & 0.273 & 0.176 \\
\hline
\end{tabular}

Table 6. Effect of the remaining toxicity of pendimethalin in clay soil on some anatomical parameters of cucumber seedling hypocotyl after it treatment with compost and $P$. putida (E15).

\begin{tabular}{lccccc}
\hline Treatment & $\begin{array}{c}\text { Seedling hypocotyl cross } \\
\text { section thick }(\mathbf{m m})\end{array}$ & $\begin{array}{c}\text { Cortex thick } \\
(\mu \mathrm{m})\end{array}$ & $\begin{array}{c}\text { Xylem thick } \\
(\mu \mathrm{m})\end{array}$ & $\begin{array}{c}\text { Number of } \\
\text { Vessels/bundle }\end{array}$ & $\begin{array}{c}\text { External phloem } \\
\text { thick }(\boldsymbol{\mu m})\end{array}$ \\
\hline Pendimethalin & 4.3 & 1720 & 464.8 & 3 & 398.4 \\
$\begin{array}{l}\text { Pendimethalin }+ \\
\text { Compost }\end{array}$ & 1.96 & 640 & 166 & 7 & 182.6 \\
$\begin{array}{l}\text { Pendimethalin }+ \\
\text { P. putida (E15) }\end{array}$ & 1.78 & & & & 166 \\
Control & 2.12 & 800 & 128 & 6 & 199.2 \\
\hline
\end{tabular}

arranged. The spongy parenchymatous cells are loosely arranged with numerous large intercellular spaces. Data presented in Table 7 and Figure 8 indicated that, anatomical parameters of the first true leaf of cucumber show similar trend as those of seedling hypocotyl. Lamina, palisade, spongy, conductive vascular tissues as well as midrib thickness were induced by pendimethalin soil treatment in compared with other treatments. Number of vessels per bundle was 3 for pendimethalin treatment and 13, 12, 14 for compost, P. putida (E15) and control (untreated with pendimethalin), respectively. It is interesting to indicate that, the internal growth parameters were concomitant with the growth parameters. No available literature was found concerning the anatomical differences, which may be useful for understanding the effect mechanisms of pendimethalin on cucumber plants.

Herbicides play an important role in the production of vegetables but their residues may cause numerous environmental problems. First of all, they may contaminate surface and groundwater through leaching and run-off. They may also remain on the soil surface and potentially affect quality and yield of the next crop cultivated on the same field. Finally, stable herbicides may be taken up by a plant forming unwanted residues. With regard to plants, pendimethalin shows differential toxicity to various species, and there is a formulation-dependent toxicity to non target plant species.

The efficacy of pendimethalin action against target organisms has been the objective of a large number of investigations, including, for example, control of Trianthema portulacastrum and effect on yield of fodder oats (Brar and Walia, 1995), control of the population of broad-leaved weeds, grass, sedges, and total weeds at definite intervals after application (Gowda and Devi, 1984), control of common vetch, Vicia sativa, and black medic, Medicago lupulina (Norcini et al., 1997).

Pendimethalin is similar to other broad-spectrum herbicides in that it is phytotoxic to crop species to some extent. In the development of herbicides, screening experiments are conducted to ascertain extent of phytotoxicity to crops. The phytotoxicity of pendimethalin to crop species has been the focus in numerous experiments, for example, rice grain, and straw yield (Devi and Gowda, 1985), root suppression of pampas grass (Green et al., 1997), effect of repeated application on cotton yield and quality, cotton fiber quality and yield (Keeling et al., 1996).

There is indication that dinitroaniline herbicides (include Pendimethalin) inhibit photosynthesis, oxidative phosphorylation, protein, nucleic acid and lipid synthesis (Moreland et al., 1972). Cotyledonary leaf and hypocotyls and first true leaf of seedling treated with pendimethalin seem to be dark green colors, swelling and brittleness. Pendimethalin treatment caused reduction in primary root length and number of lateral roots. This may be due to the fact that the ridicule is the first organ to come directly in contact with pendimethalin in the soil. Compost and $P$. putida (E15) disappeared the dark green colors and 


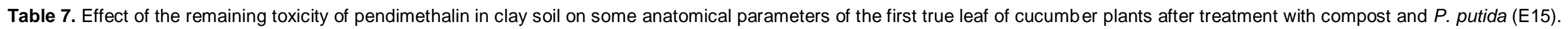

\begin{tabular}{|c|c|c|c|c|c|c|c|c|}
\hline Treatment & $\begin{array}{l}\text { Lamina thick } \\
(\mu \mathrm{m})\end{array}$ & $\begin{array}{l}\text { Palisade tissue } \\
\text { thick }(\mu \mathrm{m})\end{array}$ & $\begin{array}{c}\text { Spongy tissue } \\
\text { thick }(\mu \mathrm{m})\end{array}$ & $\begin{array}{c}\text { Midrib thick } \\
(\mu \mathrm{m})\end{array}$ & $\begin{array}{l}\text { Midrib vascular } \\
\text { bundle thick }(\mu \mathrm{m})\end{array}$ & $\begin{array}{c}\text { Xylem thick } \\
(\mu \mathrm{m})\end{array}$ & $\begin{array}{c}\text { Number of } \\
\text { Vessels/bundle }\end{array}$ & $\begin{array}{c}\text { Phloem } \\
\text { thick }(\mu \mathrm{m})\end{array}$ \\
\hline Pendimethalin & 215.8 & 66.4 & 116.2 & 1095 & 448.2 & 265.6 & 3 & 166 \\
\hline Pendimethalin + Compost & 99.6 & 16.6 & 66.4 & 999 & 365.2 & 215.8 & 13 & 116 \\
\hline Control & 189 & 66.4 & 100 & 1329 & 431.8 & 200.1 & 14 & 149 \\
\hline
\end{tabular}
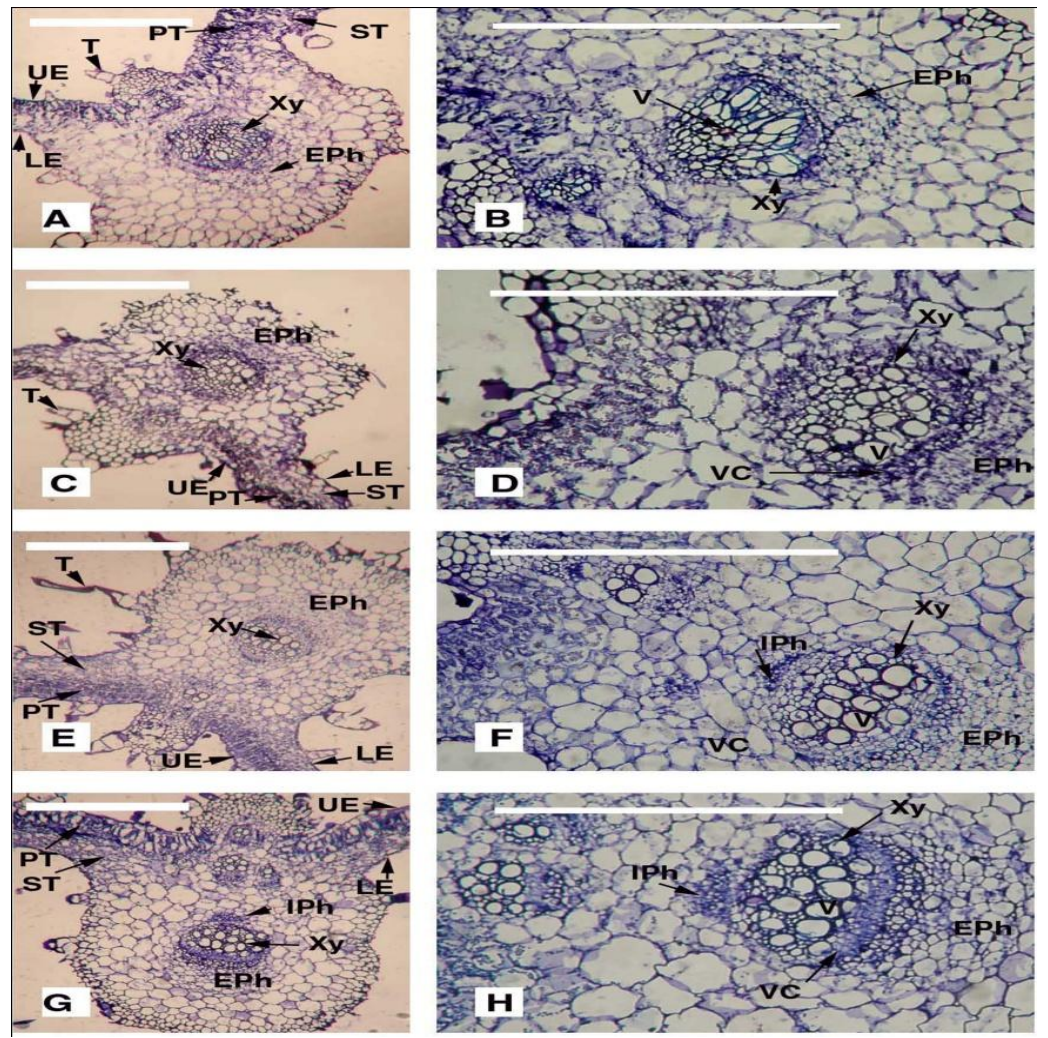

Figure 8. Cross sections through the first true leaf of cucumber plants, A-B : Pendimethalin, C-D: Pendimethalin $+P$. putida (E15), E-F: Pendimethalin + Compost, G-H: Control (untreated), Hypocotyls cavity (HC), Xylem (Xy), Externa phloem (EPh), Internal phloem (IPh), Vascular cambium (VC), Vessel (V), Upper epidermis (UE), Lower epidermis (LE), Trichome (T), Palisade tissue (PT) Spongy tissue (ST), Bar $=500 \mu \mathrm{m}$. 
improved the lateral roots. Smith (2006) recorded, that pendimethalin markedly inhibited the growth of both seedling weeds and crops. It was found that, dinitroaniline herbicides kill seedling weeds by inhibiting the development of lateral roots in susceptible plants, stunting the above-ground parts, with the development of a dark green color, swelling and brittleness of the stem or seedling hypocotyl (Parka and Soper, 1977). Severe crop phytotoxicity and damage symptoms reported in literature range from reduced or inhibited germination, reduced root length, protein and nucleic acid contents of root tips, injured flowers, to complete crop failure and residual persistence of herbicides in crop and soil (Henderson and Webber, 1993; Sinah et al., 1996). Pendimethalin caused seedling mortality (Aluka, 1997), but does not prevent seedling emergence (Akobundu, 1987; Smith, 2004; Smith, 2006). In the present study, applications of pendimethalin reduced seedling emergence lower than the other treatments. The higher seedling phytotoxicity could be attributed to pendimethalin concentration in the soil. Thus, a carryover of herbicide residues from one crop season to the following one may occur even through the development of modern herbicides has been directed toward a short half-live in the environment (Fayez and Kristen, 1996).

\section{Conclusion}

In the present study, dissipation of pendimethalin-contaminated soil was studied by the addition of pure culture from $P$. putida (E15) and compost in 28 days. $P$. putida (E15) and compost showed high ability in Pendimethalin dissipation. There is no toxicity of pendimethalin detected in clay soil after treatment with $P$. putida or compost on cucumber plants, therefore these residues do not affect the following economical crops. It was observed that clay soil without any amendment (that is control) showed least dissipation of pendimethalin. Pendimethalin significantly decreased germination rate and increased cucumber seedling mortality rate. The results suggest that bioremediation by $P$. putida (E15) strain and compost were considered to be the effective method for detoxification of pendimethalin in soil system.

\section{ACKNOWLEDGEMENT}

This work was supported by Kafrelsheikh University (Researches Support Fund), Egypt. The authors are grateful to Dr. M. M. Hassan, lecturer of Genetics, Fac. of Agriculture, Minufiya Univ., for his helpful to achieve this work.

\section{REFERENCES}

Akobundu $I O$ (1987). Weed Science in the Tropics. Principles and practices. Wiley, New York, $522 \mathrm{p}$.

Aluka OA (1997). Evaluation of pendimethalin (StompR) and a mixture of pendimethalin (StompR) and atrazine (GesaprinR) for weed control in jute (Corchorus olitorius). B. Agric. Tech. Project, The Fedral University of Technology, Akure, Nigeria. $31 \mathrm{pp}$.

Ambrus A, Lantos J, Visi E, Csatlos I, Sarvari L (1981). General method for determination of pesticide residues of plant origin, soil, and water, I. Extraction and cleanup. J. Assoc. Anal. Chem. 64: 733-742.

Appleby JR, Valverde BE (1988). Behavior of dinitroaniline herbicides in plants. Weed Technol. 3: 198-206.

Azadeh B, Meon S (2009). Molecular Characterization of Pseudomonas aeruginosa UPM P3 from Oil Palm Rhizosphere. Amer. J. Appl. Sci. 6: 1915-1919.

Barua A, Saha S, Chaudhury J, Chowdhury S, Aditya A, Chaudhury N (1991). Degradation of pendimethalin by soil fungi. Pestic. Sci. 29: $419-425$

Belal EB, Zidan NA, Mahmoud HA, Eissa FI (2008). Bioremediation of pesticides - contaminated soils. J. Agric. Res. Kafrelsheikh Univ. 34: $588-608$.

Bollag JM, Liu SY (1990). Biological transformation process of pesticides. In Pesticides in the Soil Environment, H.H. Chang, ed., Soil Sci. Soc. Am. (Madison), pp. 169-211.

Brar LS, Walia US (1995). Bioefficacy of herbicides against Trianthema portulacastrum in toria (Brassica campestris subsp. oleifera var. toria). Ind. J. Agron. 40: 647-650.

Chaudhry GR, Ali HD (1988). Bacterial metabolism of carbofuran. Appl. Environ. Microb. 54:1414 - 1419.

Cole AM, Zhang L, Liu X (1995). Remediation of pesticide contaminated soil by planting and composting addition. Compos. Sci. Util. 3: 20-30.

De Schrijver A, De Mot R (1999). Degradation of pesticides by Actinomycetes. Crit. Rev. Microbiol. 25: 85-119.

Derbalah AS, Belal EB (2008). Biodegradation and Degradation Kinetics of Cymoxanil in Aquatic System. Chem. Ecol. 24:1-12.

Devi LS, Gowda RSDB (1985). Studies on efficacy of pendimethalin: Pest. 19: 41-43.

Drenovsky RE, Richards JH (2005). Nitrogen addition increases fecundity in the desert shrub Sarcobatus vermiculatus. Oecol. 143: 349-356.

Fayez KA, Kristen U (1996). The influence of herbicides on the growth and praline content of primary roots and on the ultrastructure of root caps. Environ. Experim. Bot. 36: 71-81.

Gan J, Becker RI, Koskinen WC, Buhler DD (1996). Degradation of atrazine in two soils as a function of concentration. J. Environ. Qual. 25: $1064-1072$.

Gomez KA, Gomez AA (1984). Statistical Procedures For Agricultural Research. 2nd Ed. John Waliy and Soins.

Gowda RSDB, Devi LS (1984). Studies on efficacy of pendimethalin for Paddy. Pest. 18: 13-15.

Guo L, Bicki TJ, Felsot AS, Hinesly TD (1991). Phytotoxicity of atrazine and alachlor in soil amended with sludge, manure and activated carbon. J. Environ. Sci. Health B: Pest. Food Contam. Agric. Wastes 26: 513-527.

Gutmann M (1995). Improved staining procedures for photographic documentation of phenolic deposits in semithin sections of plant tissue. J. Microsc. 179: pp. 277-281.

Green JC, Keever GJ, Gilliam CH, Palmer CK, Olive JW, Eakes DJ (1997). Effects of preemergence-applied herbicides on pampas grass grown in containers. J. Environ. Hort. 15: 77-80.

Grigg BC, Assaf NA, Turco RF (1997). Removal of atrazine contamination in soil and liquid systems using bioaugmentation. Pestic Sci. 50: 211-220.

Gupta PK (2000). Soil analysis - chemical. In: Methods in Environmental Analysis Water Soil and Air, first ed. Agrobios, India, pp. 203-293.

Henderson CWL, Webber MJ (1993). Phytotoxicity to transplanted lettuce (Lactuca sativa) of three pre-emergence herbicides metolachlor, pendimethalin and propachlor. Aust. J. Exp. Agr. 33: 373-380.

Holding AJ, Collee JG (1971). Routine biochemical tests, in Ribbons (Academic Press, London), 6A, $1-32$.

Hong Q, Zhang Z, Hong Y, Li S (2007). A microcosm study on bioremediation of fenitrothion-contaminated soil using Burkholderia sp. FDS-1. Internat. Biodeter.\& Biod. 59: 55-61.

Jaźwa A, Szpyrka E, Sadlo (2009). Disappearance of pendimethalin in soil and its residue in ripe fennel. J. Cent. Europ. Agric. 10:153 - 158. 
John GH (1984). Ordinary gram negative bacteria. In: Bergy's Manual of Systematic Bacteriology, Baltimore. USA: Williams and Wilkins Press.

Kadian N, Gupta A, Satya S, Mehta RK, Malik A (2008). Biodegradation of herbicide (atrazine) in contaminated soil using various bioprocessed materials. Biores. Technol. 99:4642-7.

Karpouzas DG, Walker A (2000). Factors influencing the ability of Pseudomonas putida strain epl and epll to degrade the organophosphate ethoprophos. J. Appl. Microbiol. 89: 40 - 48.

Karpouzas DG, Fotopoulou A, Spiroudi UM, Singh BK (2005). Nonspecific biodegradation of the organophosphorus pesticides, cadusafos and ethoprophos, by two bacterial strains. FEMS Microb. Ecol. 53: 369-378.

Keeling JW, Dotray PA, Abernathy JR (1996). Effects of repeated applications of trifluralin and pendimethalin on cotton (Gossypium hirsutum). Weed Technol. 10: 295-298.

Kole RK, Saha J, Pal S, Chaudhuri S, Chowdhury A (1994). Bacterial degradation of the herbicide pendimethalin and activity evaluation of its metabolites. Bull. Environ. Contam. Toxicol. 52: 779-786.

Kopytko M, Chalela G, Zauscher F (2002). Biodegradation of two commercial herbicides (Gramoxone and Matancha) by the bacteria Pseudomonas putida. Elect. J. Biotechn. 5:182 -195.

Krause A, Hancock WG, Minard RD, Freye RAJ, Honeycutt RC (1985). Microbial transformation of the herbicide metolachlor by a soil actinomycete. J. Agric. Food Chem. 33: 584-589.

Kulshrestha G, Singh SB (1992). Influence of soil moisture and microbial activity on pendimethalin degradation. Bull. Environ. Contam. Toxicol. 48: 269-274.

Kyria LBM, Mervyn L, De Souza T, Raphi M, Lawrence PW, Michael LJS (1997). The atzB gene of Pseudomonas sp. strain ADP encodes the second enzyme of a novel atrazine degradation pathway. Appl. Environ. Microbiol. 63: 916-923.

Laine MM, Jorgensen KS (1996). Straw compost and bioremediated soil as inocula for the bioremediation of chlorophenol contaminated soil. Appl. Environ. Microb. 65: 1507-1513.

Leoni V, Cremisini C, Giovinazzo R, Puccetti G, Vitali M (1992). Activated sludge biodegradation test as a screening method to evaluate persistence of pesticides in soil. Sci. Total Environ., 123: 279-289.

Luke MA, Froberg JE, Masumoto HT (1975). Extraction and Cleanup of Organochlorine, Organophosphate, Organonitrogen, Hydrocarbon Pesticides in Produce for Determination by Gas-Liquid Chromatography. J. Assoc. Anal. Chem. 58: 1020-1026.

Luke MA, Froberg JE, Dosse GM, Masumoto HT (1981). Improved Multiresidue Gas Chromatographic Determination of Organophosphorus, Organonitrogen and Organohalogen Pesticides in Produce, Using Flame Photometric and Electrolytic Conductivity Detectors. J. Assoc. Anal. Chem. 64: 1187-1195.

Megadi VB, Hoskeri RS, Mulla SI, Ninnekar HZ (2010). Biodegradation of pendimethalin by Bacillus Cirulans. Indian J. Biotech. 9: $173-177$.

Moran R, Porath D (1980). Chlorophyll determination in intact tissues using N, N-Dimetyl formamide. Plant Physiol. 69: 1370-1381.

Moreland DE, Farmer FS, Hussey GG (1972). Inhibition of photosynthesis and respiration by substituted 2,4-dinitroaniline herbicides. II. Effect of responses in excised plant tissue and transplanted seedlings. Pestic. Biochem. Physiol. 2: 342-352.

Moye HA, Malagodi J, Yoh GL, Leibee K, Wislocki U (1987). Residues of avermectin B1a on rotational crops and soils following soil treatment with C14 avermectin B1a. J. Agric. Food Chem. 35: 859864.

Nayak BS, Prusty JC, Monhanty SK (1994). Effect of herbicides on bacteria, fungi and actinomycetes in sesame (Sesamum indicum) soil. Ind. J. Agric. Sci. 64: 888-890.

Norcini JG, Aldrich JH, Martin FG (1997). Preemergent control of common vetch (Vicia sativa L.) and black medic (Medicago lupulina L). J. Environ. Hort. 15: 149-152.

Oliver JE (1979). Volatilization of some herbicide-related nitrosamines from soils. J. Environ. Qual. 8: 596-601.

Parka SJ, Soper OF (1977). The physiology and mode of action of the dinitroaniline herbicides. Weed Sci. 25:79-87.
Pattanasupong A, Nagase H, Inoue M, Hirata K, Tani K, Nasu M, Miyamoto K (2004). Ability of microbial consortium to remove pesticide, carbendazim and 2,4- dichlorophenoxyacetic acid. World $\mathrm{J}$. Microbiol. Biotechnol. 20: 517-522.

Ross JA, Marco GJ (1978). CGA-48988-potatoes residues observed and metabolism data including the analytical methods used. Report no. ABR-78055. Agricultural Division, CIBA-Geigy Corp., Greensboro, N.C.

Ruzin SE (1999). Plant microtechniques and microscopy. First Ed Oxford University press, USA.

Sadło S (1998). Partition coeffi cient - its determination and significance in estimation of pesticide residue losses in the course of extraction procedure. J. PI. Protect. Res. 38: 179-184.

Saha J, Chowdhury A, Chaudhuri S (1991). Stimulation of heterotrophic dinitrogen fixation in barley root association by the herbicide pendimethalin and its metabolic transformation by Azotobacter spp. Soil Biol. Biochem. 23: 569-574.

Sambrook J, Fritsch EF, Maniatis J (1989). Molecular cloning. In: A Laboratory Manual (2nd ed.). USA: Cold Spring Harbor Laboratory.

Sidhu PS, Bhandari SC, Mehra SP, Gil HS (1985). Effect of fluchloralin, oxadiazon and pendimethalin on soil microflora and nodulation in groundnut. J. Res. Punjab Agric. Univ. 22: 33-38.

Sinha SN, Agnihotri NP, Gajdhiye VT (1996). Field evaluation of pendimethalin for weed control in onion and persistence in plant and soil. Ann. Plant Prot. Sci. 4: 71-75.

Singh SB, Kulashretha G (1991). Microbial degradation of pendimethalin. J. Environ. Sci. Health B. 26: $309-321$.

Smith AE, Aubin AJ, McIntosh TC (1995). Field persistence studies with emulsifiable concentrate and granular formulations of the herbicide pendimethalin in Saskatchewan. J. Agric. Food Chem. 43: 29882991.

Smith MAK (2004). Pendimethalin phytotoxicity and seedling weed control in Indian spinach (Basella alba L. ). Crop Prot. 23: 201-204.

Smith MAK (2006). Comparing weed and crop seedling response to pre-emergence pendimethalin application in Corchorus olitorius and Abelmoschus esculentus. Crop Prot. 25: 1221-1226.

Spain JC, Nishino SF (1987). Degradation of 1,4-dichlorobenzene by a Pseudomonas sp. Appl. Environ. Microbiol. 53: 1010-1019.

Strandberg M, Scott-Fordsmand JJ (2004). Effects of pendimethalin atlower trophic levels-a review. Ecotoxicol. Environ. Saf. 57: 190201.

Tiainen JAh, Valo R, Jarvinen M, Joutti A (2002). Microbial toxicity tests and chemical analysis as monitoring parameters at composting of creosote-contaminated soil. Ecotoxicol. Environ. Saf. 53: 323-329.

Valverde-Garcia A, González-Pradas E, Vidal JM, Agüera López A (1991). Simple and efficient multiresidue screening method for analysis of nine halogen-containing pesticides on peppers and cucumbers by GLC-ECD. J. Agric. Food Chem. 39: 2188- 2191.

Vidali M (2001). Bioremediation. An overview. Pure Appl. Chem. 73: 1163-1172.

Vogel TM (1996). Bioaugmentation as a soil bioremediation approach. Curr. Opin. Biotechnol. 7: 311-316.

Wilems A, Collins MD (1993). Phylogenetic analysis of Rhizobia and Agrobacteria based on 16s rRNA gene sequences. Int. J. Syst. Microbiol. 43: 305-313.

Zayed SM, Mostafa IA, Farghaly MM, Attaby HS, Adam YM, Mahdy FM (1983). Microbial degradation of trifluralin by Aspergillus carneus, Fusarium oxysporum and Trichoderma viride. J. Environ. Sci. Health. B. 18: 253-267.

Zheng SQ, Cooper JF (1996). Adsorption, desorption and degradation of Three pesticides in different soils. Arch. Eviron. Contam. Toxicol 30: 15-20. 